\title{
Interaction between sulfur and lead in toxicity, iron plaque formation and lead accumulation in rice plant
}

\author{
Junxing Yang ${ }^{\mathrm{a}}$, Zhiyan Liu ${ }^{\mathrm{b}}$, Xiaoming Wan ${ }^{\mathrm{a}}$, Guodi Zheng ${ }^{\mathrm{a}}$, Jun Yang ${ }^{\mathrm{a}}$, Hanzhi Zhang ${ }^{\mathrm{a}}$, \\ Lin Guo $^{c}$, Xuedong Wang ${ }^{\mathrm{d}}$, Xiaoyong Zhou ${ }^{\mathrm{a}}$, Qingjun Guo ${ }^{\mathrm{a}, *}$, Ruixiang $\mathrm{Xu}^{\mathrm{a}}$, \\ Guangdong Zhou ${ }^{a}$, Marc Peters ${ }^{a}$, Guangxu Zhu ${ }^{a}$, Rongfei Wei ${ }^{a}$, Liyan Tian ${ }^{a}$, Xiaokun Han ${ }^{a}$ \\ ${ }^{a}$ Center for Environmental Remediation, Institute of Geographic Sciences and Natural Resources Research, Chinese Academy of Sciences, Beijing 100101, \\ PR China \\ ${ }^{\mathrm{b}}$ School of Life Sciences, South China Normal University, Guangzhou 510631, PR China \\ c Department of Biological and Environmental Sciences, Texas AEM, Commerce, TX 75428, United States \\ d College of Resource Environment and Tourism, Capital Normal University, Beijing 100048, PR China
}

\section{A R T I C L E I N F O}

\section{Article history:}

Received 3 August 2015

Received in revised form

18 February 2016

Accepted 19 February 2016

Available online 4 March 2016

\section{Keywords:}

Glutathione

Iron plaque

Lead

Rice (Oryza sativa L.)

Sulfur

\begin{abstract}
A B S T R A C T
Human activities have resulted in lead and sulfur accumulation in paddy soils in parts of southern China. A combined soil-sand pot experiment was conducted to investigate the influence of $\mathrm{S}$ supply on iron plaque formation and $\mathrm{Pb}$ accumulation in rice (Oryza sativa L.) under two Pb levels $\left(0\right.$ and $\left.600 \mathrm{mg} \mathrm{kg}^{-1}\right)$, combined with four $\mathrm{S}$ concentrations $\left(0,30,60\right.$, and $\left.120 \mathrm{mg} \mathrm{kg}^{-1}\right)$. Results showed that $\mathrm{S}$ supply significantly decreased $\mathrm{Pb}$ accumulation in straw and grains of rice. This result may be attributed to the enhancement of Fe plaque formation, decrease of $\mathrm{Pb}$ availability in soil, and increase of reduced glutathione (GSH) in rice leaves. Moderate S supply ( $30 \mathrm{mg} \mathrm{kg}^{-1}$ ) significantly increased Fe plaque formation on the root surface and in the rhizosphere, whereas excessive $S$ supply $\left(60\right.$ and $\left.120 \mathrm{mg} \mathrm{kg}^{-1}\right)$ significantly decreased the amounts of iron plaque on the root surface. Sulfur supply significantly enhanced the GSH contents in leaves of rice plants under $\mathrm{Pb}$ treatment. With excessive $\mathrm{S}$ application, the rice root acted as a more effective barrier to $\mathrm{Pb}$ accumulation compared with iron plaque. Excessive $\mathrm{S}$ supply may result in a higher monosulfide toxicity and decreased iron plaque formation on the root surface during flooded conditions. However, excessive $\mathrm{S}$ supply could effectively decrease $\mathrm{Pb}$ availability in soils and reduce $\mathrm{Pb}$ accumulation in rice plants.
\end{abstract}

(c) 2016 Elsevier Inc. All rights reserved.

\section{Introduction}

Lead levels in paddy soils of China have been significantly enhanced recently by anthropogenic activities, such as mining, atmospheric deposition or irrigation with contaminated groundwater (Ye et al., 2004; Luo et al., 2011). Rice grown on Pb-contaminated paddy soil can accumulate high levels of $\mathrm{Pb}$ in shoots and grains (Zhuang et al., 2009; Liu et al., 2013). The Pb accumulated in rice plants can enter the food chain, leading to serious health risks to the human body, particularly the central nervous system of children (Wasserman et al., 1997). Thus, preventing Pb uptake and translocation in rice grown in Pb-contaminated soils is important (McLaughlin et al., 1999).

The increasing sulfur accumulation in paddy soils in southern China was confirmed by agricultural activities, such as anthropogenic $\mathrm{SO}_{2}$ emission, super-phosphate fertilization, and wastewater irrigation

\footnotetext{
* Corresponding author.

E-mail address: guoqj@igsnrr.ac.cn (Q. Guo).
}

(Hu and Xu, 2002; Wang et al., 2004). Sulfur plays an important role in regulating plant growth and development (Anjum et al., 2008). However, more $S$ accumulation in the paddy soils may disturb the uptake of other elements (e.g., As and Cd) by rice, as S can be easily affected by the change of redox potential (Eh) of paddy soils because of the transformation of the redox state of inorganic species from -2 to +6 (Hu and Xu, 2002; Hu et al., 2007; Fan et al., 2010).

The oxidizing capacity, which is characterized as radial oxygen loss (ROL), of paddy rice roots can lead to the formation of iron oxyhydroxide plaque on the root surface (Mei et al., 2012; Cheng et al., 2014; Yang et al., 2016). The effect of Fe plaque on the uptake of metals (e.g., Zn) depends on the amount of Fe plaque on the root surfaces (Otte et al., 1989; Zhang et al., 1998; Yang et al., 2014). The enhancement of Fe plaque formation was demonstrated to reduce the accumulation of $\mathrm{As}, \mathrm{Cd}$, and $\mathrm{Pb}$ in grains of rice (Hu et al., 2007; Cheng et al., 2014). Fe plaque can act as a barrier or buffer to the uptake of heavy metals probably because of the adsorption and immobilization of metals on plaque (Taylor and Crowder 1983; Liu et al., 2004; Mei et al., 2012; Yang et al., 2016). 
Sulfur may alleviate the influence of heavy metal on plant growth by $\mathrm{S}$ metabolism. Reduced glutathione (GSH), which is a low molecular weight tri-peptide, detoxifies heavy metals through the formation of phytochelatins (PCs), which can synthesize metal-PC complex and transport the complex to the vacuole (Sun et al., 2005; Khan et al., 2008; Gupta et al., 2013). In addition, S metabolism is closely linked to the biosynthesis of PCs in plants and metal sequestration (Thangavel et al., 2007). Recent experimental studies showed that S application could protect plants from heavy metal (e.g., As and Cd) toxicity because of the increase of GSH contents in the leaves of the plants $\mathrm{Hu}$ et al., 2007; Fan et al., 2010, 2013; Zhang et al., 2013). It is necessary to clarify the interaction between $\mathrm{S}$ and $\mathrm{Pb}$ in toxicity, iron plaque formation and $\mathrm{Pb}$ accumulation in rice plant. In order to evaluate variation of S supply and $\mathrm{Fe}$ plaque on $\mathrm{Pb}$ accumulation and the distribution in rice plants, the major aim of the present study was to investigate the variations and correlations in GSH contents, degrees of Fe plaque formation, and the uptake and distribution of $\mathrm{Pb}$ in shoot and root tissues and Fe plaque on root surfaces and in the rhizospheres under moderate and excessive $\mathrm{S}$ conditions.

\section{Materials and methods}

\subsection{Soil used and experimental design}

The soil used in the pot trial was collected from a hydragric paddy field $(0-20 \mathrm{~cm})$ located at Soil Fertility and Fertilizer Efficiency Long Term Monitoring Base of Qiyang City, Hunan Province, China. The soil was thoroughly mixed, air-dried, and ground to $<2 \mathrm{~mm}$. The physical and chemical properties of the soil were analyzed and presented as follows: $\mathrm{pH}$ : 5.31 ; organic matter: $22.6 \mathrm{~g} \mathrm{~kg}^{-1}$; total $\mathrm{N}$ : $1.65 \mathrm{~g} \mathrm{~kg}^{-1}$; total S: $191 \mathrm{mg} \mathrm{kg}^{-1}$; available S: $13.45 \mathrm{mg} \mathrm{kg}^{-1}$; total $\mathrm{Pb}$ : $41.99 \mathrm{mg} \mathrm{kg}^{-1}$; available $\mathrm{Pb}$ : $7.32 \mathrm{mg} \mathrm{kg}^{-1}$; available $\mathrm{Fe}$ : $128.7 \mathrm{mg} \mathrm{kg}^{-1}$; and available Mn: $25.4 \mathrm{mg} \mathrm{kg}^{-1}$.

A rhizobag system with a soil-sand combination was used to collect rhizosphere and non-rhizosphere soils separately and study the effect of S application on iron plaque formation, rice leaf GSH, and $\mathrm{Pb}$ uptake in rice plants. Six treatments were employed with two levels of $\mathrm{Pb}\left(\right.$ as $\mathrm{PbCl}_{2}$ ) [without $\mathrm{Pb}(\mathrm{Pb} 0), 600 \mathrm{mg} \mathrm{Pb} \mathrm{kg}^{-1}$ (Pb600)], combined with four levels of $\mathrm{S}\left(\mathrm{as} \mathrm{Na}_{2} \mathrm{SO}_{4}\right.$ ) [0 (S0), 30 (S30), 60 (S60), 120 (S120) $\left.\mathrm{mg} \mathrm{S} \mathrm{kg}^{-1}\right)$ ]. In total, $1.5 \mathrm{~kg}$ of dried soil was placed in each pot. The soil used was firstly spiked with $\mathrm{Pb}\left(0\right.$ and $600 \mathrm{mg} \mathrm{kg}^{-1}$ supplied as $\mathrm{PbCl}_{2}$ ), then mixed thoroughly and allowed to equilibrate for 2 months. After 2 months, the bulk soil was air-dried and passed through a 2-mm sieve, and then the air-dried $\mathrm{Pb}$ polluted-soil was spiked with $\mathrm{S}\left(030,60\right.$ and $120 \mathrm{mg} \mathrm{kg}^{-1}$ supplied as $\left.\mathrm{Na}_{2} \mathrm{SO}_{4}\right)$ and equilibrated for 1 month. After 1 month, the bulk soil was also airdried, passed through a $2-\mathrm{mm}$ sieve and then received (per $\mathrm{kg}$ ) a basal application of $100 \mathrm{mg} \mathrm{P}$ as $\mathrm{KH}_{2} \mathrm{PO}_{4} ; 125 \mathrm{mg} \mathrm{K}$ as $\mathrm{KH}_{2} \mathrm{PO}_{4}$; and $110 \mathrm{mg}$ $\mathrm{N}$ as urea. During the equilibration, the soil water was maintained at $70 \%$ of maximum water holding capacity by weight. Rhizobags, which were made of nylon netting with a mesh size of $40 \mu \mathrm{m}$, were $4 \mathrm{~cm}$ in diameter and $10 \mathrm{~cm}$ height and filled with $0.3 \mathrm{~kg}$ of quartz sand. The quartz sand was collected from Jinwuxing market, Beijing, PR China, and was not contaminated with heavy metals. Before use, the quartz sand was deionized water-washed, air-dried, and sieved ( $<2 \mathrm{~mm})$. The sand-filled rhizobags were placed in the center of each soil pot (15 cm diameter $\times 17 \mathrm{~cm}$ height). The sand-filled rhizobags were placed in the center of each soil pot. This rhizobag design could successfully prevent the roots and root hairs from entering the adjacent non-rhizosphere soil zone while allowing the transfer of microfauna and root exudates between the two compartments. This outcome meant that although the soil was used to enclose the outside portion of the rhizobag, the rhizosphere was confined to the sand compartment and effectively separated from the non-rhizosphere soil compartment (Hu et al., 2007; Yang et al., 2014, 2016). The plants were transplanted into sand at the beginning of the pot experiment, and the sand is here referred to as "rhizosphere" material and at the end of the study and the soil outside of the rhizobag is referred to as "non-rhizosphere" (the comparable soil zone). The rest of the pot outside the rhizobag was filled with $1.5 \mathrm{~kg}$ of air-dried soil. Each treatment was repeated four times. The soils were balanced at $100 \%$ of the water holding capacity for two weeks before planting.

The rice seeds of cultivar no. 12 Zhe-You were sterilized in $10 \%$ $\mathrm{H}_{2} \mathrm{O}_{2}$ (v/v) solution for $30 \mathrm{~min}$ and thoroughly washed with deionized water. The seeds were germinated in the moist filter paper at a temperature of $26^{\circ} \mathrm{C}$. In each pot, two uniform germinated seeds were transplanted into each rhizobag and grown for 120 days. Soil moisture content was increased to $100 \%$ of the water holding capacity before seedling emergence and kept submerged in deionized water for the whole growth period. All the pots were arranged randomly in the greenhouse with a relative humidity of $85 \%$ and light/dark cycle of $14 \mathrm{~h}$ day/10 h night.

\subsection{Harvest and sampling}

Before harvesting, the plant height was measured, and two pieces of fresh penultimate leaves of each plant were sampled, wrapped round with aluminum foils, and stored in liquid nitrogen for GSH analysis. The rice plants were harvested by carefully removing the rhizobags from the pots. The roots were separated from the quartz sand. The plants were divided into three parts as roots, straw, and grains. All the plants were rinsed with deionized water. The straw and grains were dried to a constant weight at $60^{\circ} \mathrm{C}$ for $48 \mathrm{~h}$, and the dry weights were recorded. The fresh roots were used for the extraction of iron plaque. The quartz sand inside the rhizobags was referred to as the rhizosphere material. The soils in the pots were homogenized thoroughly and further referred to as the non-rhizosphere soils (Hu et al., 2007).

\subsection{Extraction of iron plaque}

During harvest, one of fresh root in the rhizobag was used for $\mathrm{Pb}$, $\mathrm{Fe}$, and $\mathrm{Mn}$ on the root surface by a dithionitecitrate-bicarbonate (DCB) method (Taylor and Crowder, 1983), and the other fresh root was used for the $\mathrm{S}$ on the root surface by $1 \mathrm{M} \mathrm{HCl}$ solution (Hu et al., 2007). The quartz sand that was collected from the rhizosphere was extracted by $0.1 \mathrm{M} \mathrm{HCl}$ solution for $\mathrm{Pb}, \mathrm{Fe}, \mathrm{Mn}$, and S analysis ( $\mathrm{Hu}$ et al., 2007). The rice roots or quartz sand were immersed in $45 \mathrm{~mL}$ DCB or $\mathrm{HCl}$ solution, respectively, and shaken at $280 \mathrm{rpm}$ for $3 \mathrm{~h}$ at $25^{\circ} \mathrm{C}$. The solution was filtered with quantitative filter papers to $100 \mathrm{~mL}$ volumetric flasks, rinsed four times, and diluted to the volume with deionized water. After the extraction with $\mathrm{DCB}$ or $\mathrm{HCl}$ solution, the roots were oven dried to constant weight at $60{ }^{\circ} \mathrm{C}$ for $48 \mathrm{~h}$, and the dry weights were recorded. The dry weights of roots, straw, and grains for each plant were referred to as plant biomass.

\subsection{Plant digestions}

The oven-dried root, straw, and grain samples were homogenized using a Retsch grinder (Type: $2 \mathrm{~mm}$, Retsch Company, Germany) and digested by $\mathrm{HNO}_{3}$ (guaranteed reagent) (Alexander et al., 2006). The sub-samples of plant tissues $(0.5 \mathrm{~g})$ were digested in flasks on an electric heating plate at $60{ }^{\circ} \mathrm{C}$ and then increased to $110^{\circ} \mathrm{C}$ and kept stable until the sample solution became clear. The sample volume was adjusted to $50 \mathrm{~mL}$ with ultrapure water. Blank and reference material (BGW-07603) (China Standard Materials Research Center, Beijing, PR China) were utilized for quality control. The $\mathrm{Pb}$ recovery rates were $90 \pm 10 \%$.

\subsection{Chemical analysis}

The $\mathrm{Pb}, \mathrm{Fe}$, and $\mathrm{Mn}$ concentrations in the $\mathrm{DCB}$ extracts and $\mathrm{HCl}$ 
solution were determined by inductively coupled plasma optical emission spectrometry (ICP-MS, Elan 5000, Perkin Elmer, USA). The sulfur concentrations in the $\mathrm{HCl}$ extracts were identified by turbidimetric spectroscopy (Verma et al., 1977). Available Pb, Fe, and Mn in soils were extracted by diethylenetriamine pentaacetic acid (DTPA: 0.005 M DTPA, 0.1 M triethanolamine and $0.01 \mathrm{M} \mathrm{CaCl}_{2}$ at $\mathrm{pH} 7.3$ ) in a soil:solution ration of $1: 2(\mathrm{v} / \mathrm{v})$ (Lindsay and Norvell, 1978) and determined by ICP-MS. To determine the total $\mathrm{Pb}$ contents, the soil samples were digested in $4 \mathrm{~mL}$ of "aqua-regia" $\left(\mathrm{HNO}_{3} / \mathrm{HCl}=1 / 3, \mathrm{~V} / \mathrm{V}\right)$ (Allen, 1989) and determined by ICP-MS. Soil organic C was analyzed by potassium dichromate $\left(\mathrm{K}_{2} \mathrm{CrO}_{7}\right)$ and total $\mathrm{N}$ by the Kjeldahl method (Kirk, 1950). Soil pH was measured in the soil:water ratio of 1:2.5 (v/v). Soil total $\mathrm{S}$ was digested by $\mathrm{Mg}\left(\mathrm{NO}_{3}\right)_{2}$ (Butters and Chenery, 1959). Available $\mathrm{S}$ was extracted by $0.01 \mathrm{M} \mathrm{Ca}\left(\mathrm{H}_{2} \mathrm{PO}_{4}\right)_{2}$ (Warman and Sampson, 1992) and determined by a turbidimetric method. Available P was identified according to a Olsen method (Olsen and Sommers, 1982). The GSH content in the penultimate leaves of the rice plants was determined according to a DTNB [5, 5'dithiobis-(2-nitrobenzoic acid)] method (Griffith, 1980).

\subsection{Data analysis}

DCB extractable Fe of the root surface $\left(T_{\mathrm{DCB}-\mathrm{Pb}}\right)$ was calculated by multiplying rice tissue weight and $\mathrm{Pb}$ concentration in iron plaque, whereas the total $\mathrm{Pb}$ in the rice tissue (root, straw, and

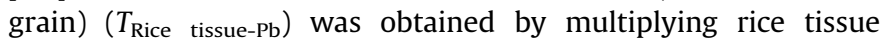
weight and $\mathrm{Pb}$ levels in each tissue. The total $\mathrm{Pb}$ amount $\left(T_{\mathrm{Pb}}\right)$ was

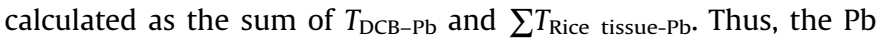
distribution in iron plaque or rice tissue was calculated by dividing $T_{\mathrm{DCB}-\mathrm{Pb}}$ or $T_{\text {Rice tissue-Pb }}$ by $T_{\mathrm{Pb}}$.

$T_{\mathrm{Pb}}(\%)=\frac{\mathrm{T}_{\mathrm{DCB}-\mathrm{Pb}} \text { or } \mathrm{T}_{\text {Rice tissue- } \mathrm{Pb}}}{\mathrm{T}_{\mathrm{DCB}-\mathrm{Pb}}+\mathrm{T}_{\text {Rice tissue }-\mathrm{Pb}}} \times 100$

where $T_{\mathrm{DCB}-\mathrm{Pb}}(\mathrm{g})$ and $T_{\text {Rice tissue-Pb }}(\mathrm{g})$ represent the $\mathrm{Pb}$ amount on root surface and $\mathrm{Pb}$ amount of tissue (root, straw and grain), respectively.

Data on plant performances were tested for their normality and variance prior to a one-way or two-way analysis of variance (ANOVA), as no data transformation was needed. If the differences between $\mathrm{Pb}$ treatments for rice plant, or among different $\mathrm{S}$ treatments for rice plant, were significant at 5\% level, the least significant difference (LSD) or $t$-test was calculated to determine where differences lay. Pearson correlation analysis was performed to establish the relationship among Cd concentrations in roots, straw, grain and DCB-extractable Fe, Mn and Cd concentrations on root surface and in the rhizosphere. All statistical analyses were performed using the SPSS 11.0 statistical package.

\section{Results}

\subsection{Plant height, biomass, and root color}

For rice grown in $600 \mathrm{mg} \mathrm{kg}^{-1} \mathrm{~Pb}, \mathrm{~S} 30, \mathrm{~S} 60$, and S120 treatments significantly $(P<0.05)$ increased plant height and biomass (roots, straws, and grains) compared with the S0 treatment (Table 1). According to the two-way analysis of variance test analysis, the biomasses of the rice were significantly influenced by $S$ doses $(P<0.01)$ and $\mathrm{Pb}$ exposures $(P<0.01)$.

The rice roots appeared reddish under S0 and S30 treatments, whereas the roots turned black with the application of S60 and S120. However, the black color was lighter on roots exposed to the $\mathrm{Pb} 600$ treatment than the color on roots treated with Pb0 (Fig. S1). Evidently, excessive $\mathrm{S}$ (S60 and S120) resulted in $\mathrm{H}_{2} \mathrm{~S}$ poison, and $\mathrm{Pb}$ addition could alleviate the poison (Fig. S2).

\subsection{Pb uptake by rice plants}

The concentration of grain $\mathrm{Pb}$ in soils without $\mathrm{Pb}$ treatment $(\mathrm{Pb} 0)$ was below the detection limit $\left(<0.01 \mathrm{mg} \mathrm{kg}^{-1}\right)$ (Table 2). When rice was grown in soil added with $\mathrm{Pb} 600$, the $\mathrm{Pb}$ levels in straw and grain of rice treated with $S$ were significantly $(P<0.05)$ lower than that in rice treated with $\mathrm{S} 0$. However, the root $\mathrm{Pb}$ concentrations were significantly $(P<0.05)$ elevated under the treatment of S60 and S120 (Table 2).

\subsection{Glutathione contents}

Under Pb600 treatment, $S$ supply significantly $(P<0.05)$ increased GSH content, and the peak value was observed at S30 treatment (Fig. 1). Under Pb0 treatment, S supply tended to increase GSH in rice leaves, but these differences were less obvious compared with that of the Pb600 treatment (Fig. 1). A higher GSH concentration resulted in the $\mathrm{Pb} 600$ treatment than in $\mathrm{Pb} 0$ treatment when rice was supplied with 30 and $60 \mathrm{mg} \mathrm{S} \mathrm{kg}^{-1}$, but no difference was observed in the other two $S$ treatments (Fig. 1).

\subsection{Concentrations of $\mathrm{Fe}, \mathrm{Mn}, \mathrm{Pb}$, and $\mathrm{S}$ in iron plaque on the root} surface and in rhizosphere quartz sand

Applying S (S60 and S120) significantly $(P<0.05)$ decreased

Table 1

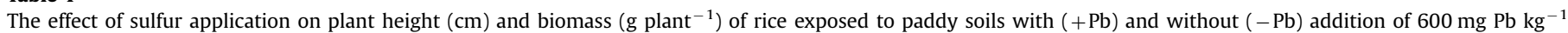
$($ mean \pm S.E., $n=4)$.

\begin{tabular}{|c|c|c|c|c|c|c|c|c|}
\hline S levels (mg/kg) & Plant height & & Root weight & & Straw weight & & Grain weight & \\
\hline & $-\mathrm{Pb}$ & $+\mathrm{Pb}$ & $-\mathrm{Pb}$ & $+\mathrm{Pb}$ & $-\mathrm{Pb}$ & $+\mathrm{Pb}$ & $-\mathrm{Pb}$ & $+\mathrm{Pb}$ \\
\hline 0 & $52.55 \pm 2.33 \mathrm{bB}$ & $60.05 \pm 1.30 \mathrm{aA}$ & $2.34 \pm 0.09 \mathrm{aA}$ & $1.32 \pm 0.05 \mathrm{cB}$ & $5.74 \pm 0.29 \mathrm{aA}$ & $4.73 \pm 0.12 \mathrm{bB}$ & $3.19 \pm 0.42 \mathrm{aA}$ & $2.21 \pm 0.04 \mathrm{cA}$ \\
\hline 30 & $56.83 \pm 1.10 \mathrm{aB}$ & $61.23 \pm 0.78 \mathrm{aA}$ & $2.47 \pm 0.04 \mathrm{aB}$ & $2.73 \pm 0.07 \mathrm{aA}$ & $5.97 \pm 0.10 \mathrm{aA}$ & $6.27 \pm 0.05 \mathrm{aA}$ & $3.31 \pm 0.06 \mathrm{aB}$ & $4.94 \pm 0.08 \mathrm{aA}$ \\
\hline 60 & $57.95 \pm 0.75 \mathrm{aA}$ & $60.43 \pm 2.12 \mathrm{aA}$ & $1.25 \pm 0.03 \mathrm{bB}$ & $2.59 \pm 0.13 \mathrm{aA}$ & $4.41 \pm 0.19 \mathrm{bB}$ & $6.03 \pm 0.28 \mathrm{aA}$ & $1.79 \pm 0.44 \mathrm{bB}$ & $4.65 \pm 0.17 \mathrm{aA}$ \\
\hline 120 & $56.30 \pm 1.01 \mathrm{abA}$ & $58.83 \pm 1.19 \mathrm{aA}$ & $0.89 \pm 0.06 \mathrm{cB}$ & $2.00 \pm 0.21 \mathrm{bA}$ & $2.29 \pm 0.16 \mathrm{cB}$ & $4.71 \pm 0.13 \mathrm{bA}$ & $0.84 \pm 0.07 \mathrm{cB}$ & $3.78 \pm 0.09 \mathrm{bA}$ \\
\hline \multicolumn{9}{|l|}{ Analysis of variance } \\
\hline $\mathrm{Pb}$ & $18.308^{* * *}$ & & $33.811^{* *}$ & & $40.19^{* * *}$ & & $97.468^{* * *}$ & \\
\hline S levels & 1.894 & & $43.337^{\text {*冰 }}$ & & $69.874^{\text {*** }}$ & & $23.17^{\text {*** }}$ & \\
\hline $\mathrm{Pb} \times \mathrm{S}$ levels & 1.428 & & $53.854^{* * *}$ & & $33.439 * *$ & & $31.327^{\text {**k }}$ & \\
\hline
\end{tabular}

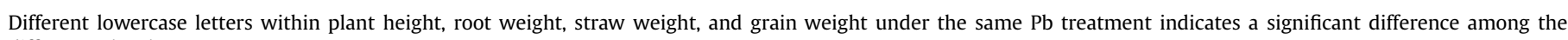
different $S$ levels at $P<0.05$.

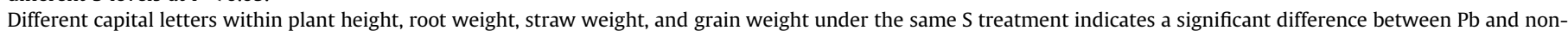
$\mathrm{Pb}$ treatments at $P<0.05$.

The effects of $\mathrm{Pb}$ treatments and $\mathrm{S}$ levels on rice tested were analyzed by the two-way analysis of variance test.

** $P<0.01$. 
Table 2

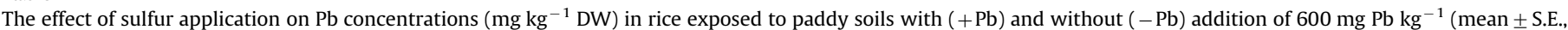
$n=4)$.

\begin{tabular}{|c|c|c|c|c|c|c|}
\hline $\mathrm{S}$ levels (mg/kg) & Root & & Straw & & Grain & \\
\hline & $-\mathrm{Pb}$ & $+\mathrm{Pb}$ & $-\mathrm{Pb}$ & $+\mathrm{Pb}$ & $-\mathrm{Pb}$ & $+\mathrm{Pb}$ \\
\hline 0 & $6.78 \pm 0.19 \mathrm{aB}$ & $896.3 \pm 9.33 \mathrm{cA}$ & $3.36 \pm 0.09 \mathrm{bB}$ & $99.23 \pm 4.9 \mathrm{aA}$ & BDL & $8.96 \pm 0.64 \mathrm{a}$ \\
\hline 30 & $6.72 \pm 0.03 \mathrm{aB}$ & $816.2 \pm 14.4 \mathrm{cA}$ & $3.21 \pm 0.07 \mathrm{bB}$ & $43.64 \pm 2.39 \mathrm{cA}$ & $\mathrm{BDL}$ & $2.24 \pm 0.05 c$ \\
\hline 60 & $6.66 \pm 0.81 \mathrm{abB}$ & $1424.6 \pm 51.36 \mathrm{bA}$ & $2.51 \pm 0.08 \mathrm{cB}$ & $71.23 \pm 3.54 \mathrm{bA}$ & BDL & $5.02 \pm 0.19 b$ \\
\hline 120 & $6.31 \pm 0.09 \mathrm{bB}$ & $1915.1 \pm 65.2 \mathrm{aA}$ & $3.65 \pm 0.05 \mathrm{aB}$ & $40.69 \pm 3.07 \mathrm{cA}$ & $\mathrm{BDL}$ & $2.27 \pm 0.09 \mathrm{c}$ \\
\hline \multicolumn{7}{|c|}{ Analysis of variance } \\
\hline $\mathrm{Pb}$ & $3502.263^{* * *}$ & & $1132.449^{* * *}$ & & & \\
\hline S levels & $145.103^{* *}$ & & $57.506^{* * *}$ & & $88.114^{* * *}$ & \\
\hline $\mathrm{Pb} \times \mathrm{S}$ levels & $145.324^{* * *}$ & & 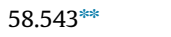 & & & \\
\hline
\end{tabular}

Different lowercase letters within root, straw and grain under the same Pb treatment indicates a significant difference among the different $\mathrm{S}$ levels at $P<0.05$. Different capital letters within root, straw and grain under the same $\mathrm{S}$ treatment indicates a significant difference between $\mathrm{Pb}$ and non-Pb treatments at $P<0.05$. ** $P<0.01$

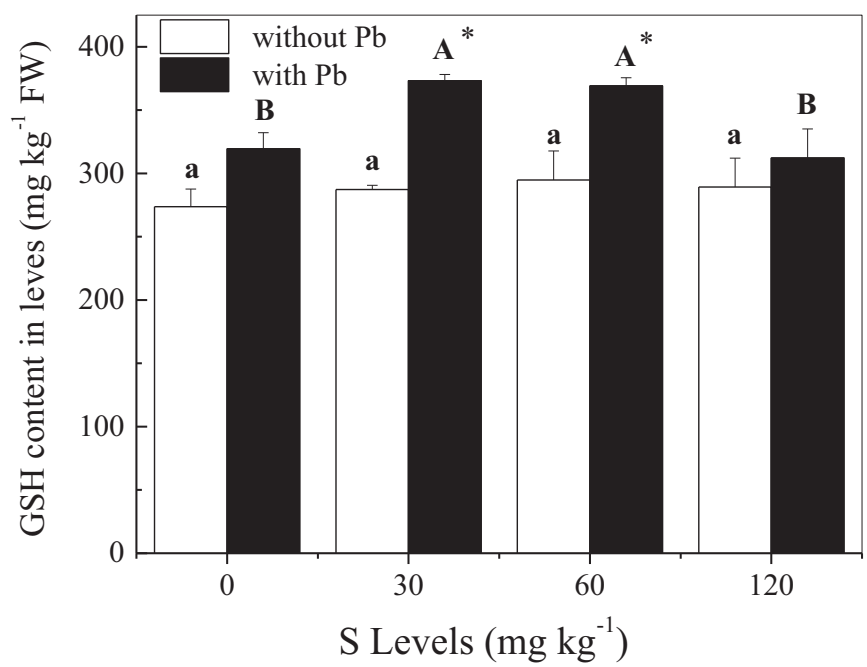

Fig. 1. The effect of S application on GSH content in the penultimate leaves of rice $\left(\mathrm{mg} \mathrm{kg}^{-1}, \mathrm{FW}\right)$ exposed to paddy soils with (-) and without ( $\square$ ) addition of $600 \mathrm{mg}$ $\mathrm{Pb} \mathrm{kg}^{-1}$ [different upper- and lower-case letters indicate significant difference at $P<0.05$ (LSD test) for $S$ levels with and without addition of $600 \mathrm{mg} \mathrm{Pb} \mathrm{kg}{ }^{-1}$, respectively; * indicates a significant difference between $\mathrm{Pb}$ and non-Pb treatments under the same $\mathrm{S}$ level at $P<0.05$ ( $t$-test)].
DCB-extractable $\mathrm{Fe}, \mathrm{Mn}$, and $\mathrm{Pb}$ concentrations in iron plaque and significantly $(P<0.05)$ increased $\mathrm{HCl}$-extractable $\mathrm{S}$ concentrations in iron plaque, irrespective of $\mathrm{Pb}$ addition (Table 3 ). The addition of $\mathrm{Pb}$ significantly $(P<0.05)$ increased DCB-extractable $\mathrm{Fe}, \mathrm{Mn}$, and $\mathrm{Pb}$ as well as $\mathrm{HCl}$-extractable $\mathrm{S}$ concentrations in iron plaque, irrespective of $\mathrm{S}$ addition (Table 3 ).

Interactions between $\mathrm{S}$ and $\mathrm{Pb}$ addition occurred on $\mathrm{DCB}-\mathrm{ex}$ tractable $\mathrm{Fe} / \mathrm{Mn}$ and $\mathrm{HCl}$-extractable $\mathrm{S}$ concentrations in iron plaque. The highest DCB-extractable Fe and Mn concentrations in iron plaque were obtained at S30 combined Pb600 treatment, whereas the lowest values were obtained at $\mathrm{S} 120$ combined $\mathrm{Pb0}$ treatment (Table 3 ). The highest $\mathrm{HCl}$-extractable $\mathrm{S}$ concentration in iron plaque was observed at $\mathrm{S} 120$ combined Pb600 treatment, whereas the lowest value was found at S0 combined Pb0 treatment (Table 3).

$\mathrm{HCl}$-extractable $\mathrm{Fe}$ and $\mathrm{Mn}$ concentrations were significantly $(P<0.05)$ higher in the rhizosphere with $\mathrm{S}$ than those without $\mathrm{S}$ addition, irrespective of $\mathrm{Pb}$ addition (Table 3). The addition of $\mathrm{Pb}$ increased $\mathrm{HCl}$-extractable $\mathrm{Fe}$ and $\mathrm{Mn}$ concentrations in the rhizosphere $(P<0.05)$, irrespective of $\mathrm{S}$ addition (Table 6$)$. Interactions between $\mathrm{S}$ and $\mathrm{Pb}$ addition occurred on $\mathrm{HCl}$-extractable $\mathrm{Fe}$ concentrations in the rhizosphere. The highest $\mathrm{HCl}$-extractable $\mathrm{Fe}$ concentration in the rhizosphere was obtained at $30 \mathrm{mg} \mathrm{S} \mathrm{kg}^{-1}$ combined Pb600 treatment, whereas the lowest value was obtained at S0 combined Pb0 treatment (Table 3).

Table 3

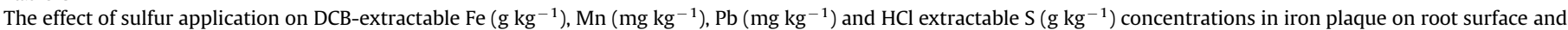
in the rhizosphere of rice exposed to paddy soils with $(+\mathrm{Pb})$ and without $(-\mathrm{Pb}$ ) addition of $600 \mathrm{mg} \mathrm{Pb} \mathrm{kg}-1$ (mean $\pm \mathrm{S} . \mathrm{E}$., $n=4$ ).

\begin{tabular}{|c|c|c|c|c|c|c|c|c|}
\hline $\mathrm{S}$ levels $\left(\mathrm{mg} \mathrm{kg}^{-1}\right)$ & DCB-Fe & & DCB-Mn & & DCB-Pb & & $\mathrm{HCl}-\mathrm{S}$ & \\
\hline & $-\mathrm{Pb}$ & $+\mathrm{Pb}$ & $-\mathrm{Pb}$ & $+\mathrm{Pb}$ & $-\mathrm{Pb}$ & $+\mathrm{Pb}$ & $-\mathrm{Pb}$ & $+\mathrm{Pb}$ \\
\hline \multicolumn{9}{|l|}{ Root surface } \\
\hline 0 & $26.32 \pm 1.81 \mathrm{bB}$ & $38.96 \pm 1.27 \mathrm{bA}$ & $94.32 \pm 3.55 \mathrm{bB}$ & $131.25 \pm 3.63 \mathrm{bA}$ & $25.9 \pm 2.23 \mathrm{aB}$ & $211.3 \pm 14.87 \mathrm{bA}$ & $0.55 \pm 0.03 \mathrm{dA}$ & $0.67 \pm 0.04 \mathrm{cA}$ \\
\hline 30 & $39.41 \pm 0.88 \mathrm{aB}$ & $67.23 \pm 3.26 \mathrm{aA}$ & $138.46 \pm 3.08 \mathrm{aB}$ & $197.94 \pm 4.39 \mathrm{aA}$ & $25.3 \pm 0.41 \mathrm{aB}$ & $289.3 \pm 4.52 \mathrm{aA}$ & $1.14 \pm 0.02 \mathrm{cB}$ & $1.57 \pm 0.04 \mathrm{bA}$ \\
\hline 60 & $16.63 \pm 0.54 \mathrm{cB}$ & $21.58 \pm 1.18 \mathrm{cA}$ & $64.21 \pm 2.72 \mathrm{cA}$ & $71.69 \pm 3.39 \mathrm{bA}$ & $24.3 \pm 1.11 \mathrm{aB}$ & $155.9 \pm 5.32 \mathrm{cA}$ & $1.39 \pm 0.05 b B$ & $1.61 \pm 0.07 \mathrm{bA}$ \\
\hline 120 & $12.45 \pm 0.82 \mathrm{~dB}$ & $18.94 \pm 0.62 \mathrm{cA}$ & $50.28 \pm 1.00 \mathrm{~dB}$ & $77.38 \pm 2.96 \mathrm{bA}$ & $23.8 \pm 1.19 \mathrm{aB}$ & $99.8 \pm 5.46 \mathrm{dA}$ & $2.45 \pm 0.07 \mathrm{aB}$ & $3.44 \pm 0.13 \mathrm{aA}$ \\
\hline \multicolumn{9}{|c|}{ Analysis of variance } \\
\hline $\mathrm{Pb}$ & $141.336^{* *}$ & & $206.027^{* * *}$ & & $1403.683^{* *}$ & & $93.254^{\text {**⿰冫⿰亅⿱丿丶丶 }}$ & \\
\hline S levels & $244.579^{* * *}$ & & $455.284^{* * *}$ & & $86.601^{* * *}$ & & $459.067 * *$ & \\
\hline $\mathrm{Pb} \times \mathrm{S}$ levels & $22.873^{* * *}$ & & $22.453 * *$ & & $83.472^{* *}$ & & $18.2^{* * *}$ & \\
\hline \multicolumn{9}{|l|}{ Rhizosphere } \\
\hline 0 & $14.29 \pm 0.77 \mathrm{cB}$ & $25.28 \pm 1.27 \mathrm{bA}$ & $1.35 \pm 0.15 \mathrm{abA}$ & $1.68 \pm 0.19 \mathrm{bA}$ & $0.085 \pm 0.006 \mathrm{abB}$ & $0.35 \pm 0.03 \mathrm{aA}$ & $0.16 \pm 0.02 \mathrm{dA}$ & $0.21 \pm 0.03 \mathrm{dA}$ \\
\hline 30 & $33.72 \pm 1.60 \mathrm{bB}$ & $48.14 \pm 1.76 \mathrm{aA}$ & $1.92 \pm 0.05 \mathrm{aB}$ & $2.57 \pm 0.03 \mathrm{aA}$ & $0.114 \pm 0.011 \mathrm{aB}$ & $0.31 \pm 0.02 \mathrm{abA}$ & $2.41 \pm 0.03 \mathrm{cA}$ & $2.33 \pm 0.03 \mathrm{cA}$ \\
\hline 60 & $23.34 \pm 1.19 \mathrm{bB}$ & $47.56 \pm 6.16 \mathrm{aA}$ & $1.13 \pm 0.14 \mathrm{bA}$ & $1.54 \pm 0.23 \mathrm{bA}$ & $0.105 \pm 0.016 \mathrm{abB}$ & $0.26 \pm 0.04 \mathrm{abA}$ & $5.73 \pm 0.12 \mathrm{bA}$ & $5.41 \pm 0.09 \mathrm{bA}$ \\
\hline 120 & $19.34 \pm 0.99 \mathrm{aB}$ & $26.69 \pm 2.39 \mathrm{bA}$ & $1.72 \pm 0.32 \mathrm{abA}$ & $1.68 \pm 0.32 \mathrm{bA}$ & $0.074 \pm 0.004 \mathrm{bB}$ & $0.23 \pm 0.02 \mathrm{bA}$ & $10.21 \pm 0.48 \mathrm{aA}$ & $9.87 \pm 0.14 \mathrm{aA}$ \\
\hline \multicolumn{9}{|c|}{ Analysis of variance } \\
\hline $\mathrm{Pb}$ & $60.216^{* * *}$ & & $5.268^{*}$ & & $144.861^{* * *}$ & & 1.707 & \\
\hline S levels & $29.881^{* *}$ & & $7.185^{\text {冰 }}$ & & $3.636^{*}$ & & $1051.166^{* * *}$ & \\
\hline $\mathrm{Pb} \times \mathrm{S}$ levels & $3.9 *$ & & 0.93 & & 2.579 & & 0.516 & \\
\hline
\end{tabular}

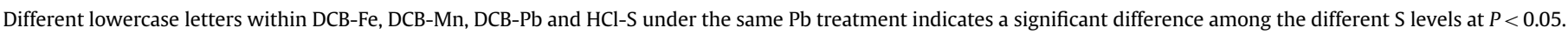

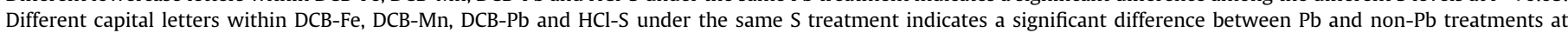
$P<0.05$.

$$
\begin{aligned}
& * P<0.05 . \\
& * * \quad P<0.01 .
\end{aligned}
$$


Table 4

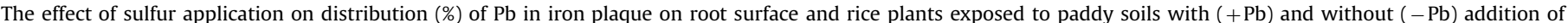
$600 \mathrm{mg} \mathrm{Pb} \mathrm{kg}^{-1}$ (mean \pm S.E., $n=4$ ).

\begin{tabular}{|c|c|c|c|c|c|c|c|c|}
\hline $\mathrm{S}$ levels $\left(\mathrm{mg} \mathrm{kg}^{-1}\right)$ & DCB-Fe on root surface & & Root & & Straw & & Grain & \\
\hline & $-\mathrm{Pb}$ & $+\mathrm{Pb}$ & $-\mathrm{Pb}$ & $+\mathrm{Pb}$ & $-\mathrm{Pb}$ & $+\mathrm{Pb}$ & $-\mathrm{Pb}$ & $+\mathrm{Pb}$ \\
\hline 0 & $62.95 \pm 2.03 \mathrm{aA}$ & $14.27 \pm 0.78$ bB & $16.75 \pm 1.17 \mathrm{aB}$ & $61.96 \pm 1.85 \mathrm{dA}$ & $20.30 \pm 1.44 \mathrm{abA}$ & $24.01 \pm 0.78 \mathrm{aA}$ & BDL & $1.02 \pm 0.06 \mathrm{a}$ \\
\hline 30 & $63.59 \pm 0.51 \mathrm{aA}$ & $23.94 \pm 0.66 \mathrm{aB}$ & $16.90 \pm 0.24 \mathrm{aB}$ & $67.46 \pm 0.26 \mathrm{cA}$ & $19.50 \pm 0.39 \mathrm{bA}$ & $8.27 \pm 0.51 \mathrm{bB}$ & BDL & $0.34 \pm 0.01 \mathrm{c}$ \\
\hline 60 & $60.95 \pm 1.44 \mathrm{aA}$ & $8.93 \pm 0.59 \mathrm{cB}$ & $16.76 \pm 0.41 \mathrm{aB}$ & $81.04 \pm 0.75 \mathrm{bA}$ & $22.30 \pm 1.20 \mathrm{abA}$ & $9.52 \pm 0.83 \mathrm{bB}$ & BDL & $0.51 \pm 0.03 \mathrm{~b}$ \\
\hline 120 & $60.10 \pm 1.76 \mathrm{aA}$ & $4.73 \pm 0.33 \mathrm{~dB}$ & $15.99 \pm 0.57 \mathrm{aB}$ & $90.37 \pm 0.70 \mathrm{aA}$ & $23.92 \pm 1.63 \mathrm{aA}$ & $4.69 \pm 0.64 \mathrm{cB}$ & BDL & $0.21 \pm 0.03 \mathrm{~d}$ \\
\hline \multicolumn{9}{|l|}{ Analysis of variance } \\
\hline $\mathrm{Pb}$ & $3465.97^{* * *}$ & & $8502.859^{\text {***⿰冫⿰亅⿱丿丶丶 }}$ & & $188.429^{* * *}$ & & & \\
\hline S levels & $35.187^{* * *}$ & & $97.968^{* * *}$ & & $28.296^{* *}$ & & $87.007^{* * *}$ & \\
\hline $\mathrm{Pb} \times \mathrm{S}$ levels & $16.521^{* * *}$ & & $108.28^{* * *}$ & & $45.378^{* * *}$ & & & \\
\hline
\end{tabular}

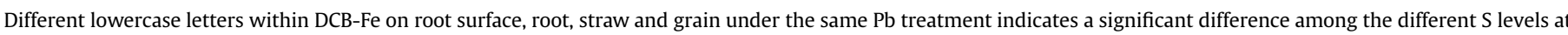
$P<0.05$.

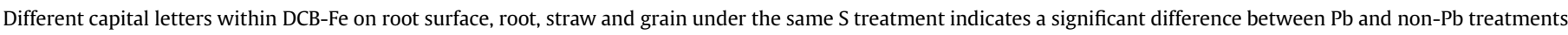
at $P<0.05$.

** $P<0.01$.

Table 5

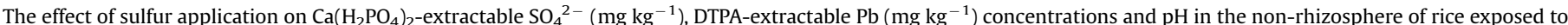
paddy soils with $(+\mathrm{Pb})$ and without $(-\mathrm{Pb})$ addition of $600 \mathrm{mg} \mathrm{Pb} \mathrm{kg}^{-1}$ (mean \pm S.E., $n=4$ ).

\begin{tabular}{|c|c|c|c|c|c|c|}
\hline $\mathrm{S}$ levels $\left(\mathrm{mg} \mathrm{kg}^{-1}\right)$ & $\mathrm{Ca}\left(\mathrm{H}_{2} \mathrm{PO}_{4}\right)_{2}-\mathrm{SO}_{4}{ }^{2-}$ & & DTPA-Pb & & $\mathrm{pH}$ & \\
\hline & $-\mathrm{Pb}$ & $+\mathrm{Pb}$ & $-\mathrm{Pb}$ & $+\mathrm{Pb}$ & $-\mathrm{Pb}$ & $+\mathrm{Pb}$ \\
\hline 0 & $14.03 \pm 0.26 \mathrm{dA}$ & $11.4 \pm 0.22 \mathrm{~dB}$ & $7.44 \pm 0.08 \mathrm{bB}$ & $327.78 \pm 5.16 \mathrm{aA}$ & $5.56 \pm 0.09 \mathrm{bA}$ & $5.67 \pm 0.08 \mathrm{aA}$ \\
\hline 30 & $87.24 \pm 1.67 \mathrm{cA}$ & $61.24 \pm 1.05 \mathrm{cB}$ & $7.89 \pm 0.08 \mathrm{abB}$ & $308.21 \pm 6.75 \mathrm{abA}$ & $5.61 \pm 0.01 \mathrm{abB}$ & $5.68 \pm 0.01 \mathrm{aA}$ \\
\hline 60 & $115.88 \pm 1.36 \mathrm{bA}$ & $96.25 \pm 2.76 \mathrm{bB}$ & $8.17 \pm 0.63 \mathrm{abB}$ & $283.99 \pm 2.96 \mathrm{bA}$ & $5.74 \pm 0.19 \mathrm{aA}$ & $5.76 \pm 0.03 \mathrm{aA}$ \\
\hline 120 & $142.70 \pm 1.53 \mathrm{aA}$ & $129.63 \pm 1.99 \mathrm{aB}$ & $11.89 \pm 0.68 \mathrm{aB}$ & $206.54 \pm 21.6 \mathrm{cA}$ & $5.73 \pm 0.13 \mathrm{aA}$ & $5.71 \pm 0.04 \mathrm{aA}$ \\
\hline \multicolumn{7}{|l|}{ Analysis of variance } \\
\hline $\mathrm{Pb}$ & $190.14^{* * *}$ & & $2194.652^{* *}$ & & 2.167 & \\
\hline S levels & $2257.819^{* * *}$ & & 20.398 *** & & $3.195^{*}$ & \\
\hline $\mathrm{Pb} \times \mathrm{S}$ levels & 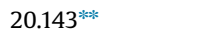 & & $21.034^{* *}$ & & 0.535 & \\
\hline
\end{tabular}

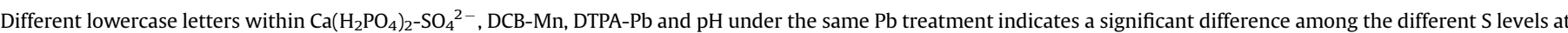
$P<0.05$.

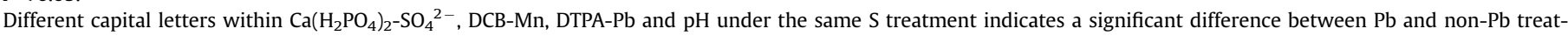
ments at $P<0.05$.

$* P<0.05$.

*** $P<0.01$.

\subsection{Lead distribution in iron plaque and rice plants}

In the $\mathrm{Pb} 0$ combined $\mathrm{S} 0$ treatment, $\mathrm{Pb}$ was predominately distributed in the following order: iron plaque $>$ roots $>$ straw. No significant difference was observed for $\mathrm{Pb}$ distribution in iron plaque and roots except in straw (Table 4). However, in Pb600combined $\mathrm{S} 0$ treatment, $\mathrm{Pb}$ was predominately distributed in the rice roots and iron plaque, followed by the straws and grains. Under Pb600 treatment, applying S (S60 and S120) significantly $(P<0.05)$ decreased $\mathrm{DCB}$-extractable $\mathrm{Pb}$ distribution in iron plaque, but significantly $(P<0.05)$ increased $\mathrm{Pb}$ levels in the roots. The addition of $S$ significantly $(P<0.05)$ decreased the distribution of straw $\mathrm{Pb}$ and grain $\mathrm{Pb}$ under the $\mathrm{Pb} 600$ treatment (Table 4).

\subsection{Concentrations of $\mathrm{Ca}\left(\mathrm{H}_{2} \mathrm{PO}_{4}\right)_{2}$-extractable $\mathrm{SO}_{4}{ }^{2-}$, DTPA-ex- tractable $\mathrm{Pb}$, and $\mathrm{pH}$ in the non-rhizosphere soil}

Irrespective of $\mathrm{Pb}$ addition, the concentrations of $\mathrm{Ca}\left(\mathrm{H}_{2} \mathrm{PO}_{4}\right)_{2}-$ extractable $\mathrm{SO}_{4}{ }^{2-}$ were significantly higher $(P<0.01)$ in the nonrhizosphere soils with $\mathrm{S}$ addition than that in the non-rhizosphere soils without S addition (Table 5). In S60 and S120 treatments, Pb addition $(\mathrm{Pb600})$ significantly $(P<0.05)$ decreased the concentrations of $\mathrm{Ca}\left(\mathrm{H}_{2} \mathrm{PO}_{4}\right)_{2}$-extractable $\mathrm{SO}_{4}{ }^{2-}$ in the non-rhizosphere soils.

Lead addition significantly increased $(P<0.05)$ DTPA-extractable $\mathrm{Pb}$ concentrations in the non-rhizosphere soils compared with that of the $\mathrm{Pb0}$ treatment, irrespective of $\mathrm{S}$ addition (Table 5). No significant difference was observed in soil $\mathrm{pH}$ with respect to $\mathrm{S}$ treatments and $\mathrm{Pb}$ addition (Table 5).

\subsection{Correlation analysis}

Significant negative correlations were found between $\mathrm{HCl}-\mathrm{ex}$ tractable S concentrations and Fe and Mn concentrations on the root surfaces and in the rhizosphere (Table 6). Significant negative correlations were also found between grain $\mathrm{Pb}$ concentrations and $\mathrm{HCl}-\mathrm{ex}$ tractable $\mathrm{S}$ concentrations on the root surfaces and in the rhizosphere.

Significant positive correlations were determined among DCBFe, DCB-Mn, and DCB-Pb concentrations on the root surfaces and sand surfaces under both $\mathrm{Pb}$ treatments (Table 6).

\section{Discussion}

\section{1. $S$ and $\mathrm{Pb}$ toxicity}

The results indicated that $\mathrm{S}$ could alleviate $\mathrm{Pb}$ stress on rice, whereas $\mathrm{Pb}$ also could mitigate excessive S-induced stress on rice. Excessive $\mathrm{S}$ resulted in $\mathrm{H}_{2} \mathrm{~S}$ poison, but some heavy metals (e.g. $\mathrm{Cd}$, and As) addition could alleviate the poison (Hu et al., 2007; Fan et al., 2010, 2013). The differences of root surface color and biomass between $\mathrm{Pb0}$ and $\mathrm{Pb} 600$ treatments also strongly demonstrated that $\mathrm{Pb}$ could mitigate excessive S-induced stress on rice (Table 1, Fig. S1).

Sulfur may alleviate the influence of $\mathrm{Pb}$ on rice growth in two mechanisms. First, $\mathrm{S}$ induced the increase of GSH for the synthesis $\mathrm{PCs}$, thus increasing $\mathrm{Pb}$ tolerance of plants. In this study, S30 and S60 treatments caused an evident increase in GSH content in rice leaves with $\mathrm{Pb}$ stress (Fig. 1). Previous research also indicated that 
Table 6

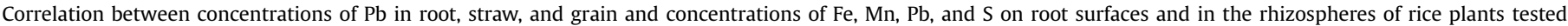
$(n=32)$.

\begin{tabular}{|c|c|c|c|c|c|c|c|c|c|c|c|}
\hline & Fe root surface & $\mathrm{Fe}_{\text {rhizosphere }}$ & Mn root surface & Mn rhizosphere & $\mathrm{Pb}$ root surface & $\mathrm{Pb}$ rhizosphere & $\mathrm{Pb}$ root & $\mathrm{Pb}_{\text {straw }}$ & $\mathrm{Pb}$ grain & $S_{\text {root surface }}$ & $S_{\text {rhizosphere }}$ \\
\hline Fe $e_{\text {root surface }}$ & 1 & $0.529 * *$ & $0.972^{\text {*** }}$ & $0.601^{\text {*** }}$ & $0.727^{* * *}$ & $0.519 * *$ & 0.043 & 0.285 & -0.133 & -0.343 & $-0.609^{* * *}$ \\
\hline Fe rhizosphere & & 1 & $0.457^{* * *}$ & $0.356^{*}$ & $0.635^{* * *}$ & $0.497^{\text {*** }}$ & $0.424^{*}$ & $0.399^{*}$ & -0.331 & 0.063 & -0.08 \\
\hline Mn root surface & & & 1 & $0.61^{* * *}$ & $0.675^{* *}$ & $0.504^{* * *}$ & 0.029 & 0.26 & -0.093 & $-0.363^{*}$ & $-0.635^{* *}$ \\
\hline Mn rhizosphere & & & & 1 & $0.471^{\text {*** }}$ & $0.387^{*}$ & 0.128 & 0.165 & -0.362 & 0.041 & -0.078 \\
\hline $\mathrm{Pb}$ root surface & & & & & 1 & $0.849^{* * * *}$ & $0.543^{* * * ⿰ ㇇ ⿰ 亅 ⿱ 丿 丶 丶 ~}$ & $0.763^{* *}$ & 0.072 & -0.066 & -0.311 \\
\hline $\mathrm{Pb}$ rhizosphere & & & & & & 1 & $0.664^{* * *}$ & $0.854^{* *}$ & 0.348 & -0.037 & -0.251 \\
\hline $\mathrm{Pb}$ root & & & & & & & 1 & $0.684^{* * *}$ & -0.399 & $0.529^{* * *}$ & 0.276 \\
\hline $\mathrm{Pb}$ straw & & & & & & & & 1 & 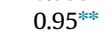 & -0.085 & -0.236 \\
\hline $\mathrm{Pb}$ grain & & & & & & & & & 1 & $-0.728^{* * *}$ & $-0.631^{* *}$ \\
\hline$S$ root surface & & & & & & & & & & 1 & $0.897^{* * * *}$ \\
\hline$S_{\text {rhizosphere }}$ & & & & & & & & & & & 1 \\
\hline
\end{tabular}

*** $P<0.01$

$* P<0.05$.

exposure to $\mathrm{Pb}$ stress initially resulted in an increased consumption of GSH for PC production, whereas GSH content will recover to a higher level after prolonged $\mathrm{Pb}$ exposure (Verma and Dubey, 2003; Islam et al., 2008; Gupta et al., 2013). Phytochelatins and Pb could form Pb-PCs chelate complex and be taken up into the vacuole (Sun et al., 2005; Gupta et al., 2013). This condition further decreased $\mathrm{Pb}$ transportation from roots to shoots in plant and alleviated $\mathrm{Pb}$ stress (Verma and Dubey, 2003). However, the GSH decreased in rice leaves treated with Pb600 and S120 (Fig. 1). This outcome indicated that $\mathrm{S}$-rich compounds induced by $\mathrm{Pb}$ tolerance could be related to $S$ levels. Second, the application of excessive $S$ decreased $\mathrm{Pb}$ uptake into rice by decreasing $\mathrm{Pb}$ availability in soil because of the formation of $\mathrm{PbS}$ precipitates (Table 6).

\subsection{Fe plaque formation}

In this study, various $\mathrm{S}$ doses exhibited different effects on Fe plaque formation under $\mathrm{Pb0}$ and $\mathrm{Pb} 600$ exposures. The present results strongly suggested that moderate S supply caused an evident increase in Fe formation on root surface and in the rhizosphere, whereas excessive S supply could decrease the formation of iron-manganese oxides plaque on the root surface (Table 3 ). Excessive $S$ that induced the decrease of plaque formation is probably attributed to an increase in the formation of abundant $\mathrm{S}^{2-}$ in bulk soil (non-rhizosphere) and the root surface. In this study, the $0.01 \mathrm{M} \mathrm{Ca}\left(\mathrm{H}_{2} \mathrm{PO}_{4}\right)_{2}$-extractable $\mathrm{SO}_{4}{ }^{2-}$ concentrations in S-supplied non-rhizosphere soil ranged from $61 \mathrm{mg} \mathrm{kg}^{-1}$ (S30 combined with Pb600 treatment) to $142 \mathrm{mg} \mathrm{kg}^{-1}$ (S120 with $\mathrm{Pb0}$ treatment), which are greater than the S deficiency critical value (12 $\mathrm{mg} \mathrm{kg}^{-1}$ ) ( $\mathrm{Hu}$ and $\left.\mathrm{Xu}, 2002\right)$. Under flooded conditions, large amounts of $\mathrm{Fe}^{2+}, \mathrm{Mn}^{2+}$, and $\mathrm{S}^{2-}$ can be produced by $\mathrm{SO}_{4}{ }^{2-}$ reducing bacteria or the metabolic activities of microorganisms (Murase and Kimura, 1997; Canfield et al., 2005). Thus, the $S^{2-}$ in bulk soil (non-rhizosphere) and on the root surfaces could result in FeS and MnS precipitation, thus ultimately inducing the decrease in iron plaque formation and/or lower stability of iron plaque. Previous studies also suggested that $\mathrm{S}$ application can increase or decrease the formation of iron plaque of rice (Hu et al., 2007; Fan et al., 2010, 2013). The outcome depends on the concentrations and species of S fertilization applied, capacities of root oxidization, rice growth stage, available $S$ concentrations in tested soil, or species of metal exposure (Hu et al., 2007; Mei et al., 2012; Fan et al., 2010, 2013). Our results, together with previous reports, suggest that the concentrations of $S$ applied may play an important role in iron plaque formation on the root surface of rice.

\subsection{Pb uptake and distribution}

In this study, the concentrations and distribution of $\mathrm{Pb}$ in straw and grains of rice decreased with the increasing rates of S application (Tables 2 and 4 ). This result strongly suggested that $\mathrm{S}$ supply could significantly decrease $\mathrm{Pb}$ uptake by rice. Our studies found that different rates of S supply undergo different mechanisms to decrease $\mathrm{Pb}$ uptake and accumulation in rice.

Under the moderate S (S30) treatment, Fe plaque formation on the root surface and in the rhizosphere was significantly enhanced. Iron plaque was reported to be likely a barrier to the adsorption, uptake, and accumulation of heavy metals (e.g., As, Cd, and $\mathrm{Zn}$ ) on rice surfaces (Liu et al., 2011; Mei et al., 2012). Significant positive correlations were also found between DCB-Fe, DCB-Mn, and DCB-Pb concentrations on root surfaces and sand surfaces under both $\mathrm{Pb}$ treatments (Table 6). This result suggested that Fe plaque induced by moderate $\mathrm{S}$ supply could adsorb more $\mathrm{Pb}$ on the root surface and in the rhizosphere. However, the effects of Fe plaque on metal uptake and translocation by wetland plants (rice) are still unclear (Ye et al., 1998; Liu et al., 2004; Cheng et al., 2014). Fe plaque formation was reported to reduce $\mathrm{Pb}, \mathrm{Cd}$, and As uptake and translocation in rice with higher rates of ROL (Mei et al., 2009; Cheng et al., 2014). On the contrary, other reports showed that metal uptake by plants was facilitated or unaffected by Fe plaque formation (Ye et al., 1998). The functions of Fe plaque on metal uptake may depend on the amount of Fe/Mn deposition on the root surfaces and metal bioavailability in the rhizosphere.

The excessive S supply (S60 and S120) significantly decreased the iron plaque on the root surface. Under $\mathrm{Pb} 600$ treatment, $\mathrm{Pb}$ was predominately distributed in rice roots, irrespective of S supply, followed by iron plaque, straws, and grain (Table 4). These results indicated that the rice root was more effective in preventing $\mathrm{Pb}$ from entering the plants than iron plaque under excessive $S$ treatments. Similarly, most of the absorbed $\mathrm{Pb}$ was reported to accumulate in the outer cortex of roots of wetland plants (Ye et al., 1998; Vesk et al., 1999; Yang et al., 2010). By using energy dispersive X-ray microanalysis, Vesk et al. (1999) found that $\mathrm{Pb}$ was not localized at the root surface and increased toward the root center of water hyacinth (Eichhornia crassipes). Liu et al. (2011) indicated that iron plaque on rice roots can reduce $\mathrm{Pb}$ uptake only in relatively mild or moderate $\mathrm{Pb}$-contaminated soil. The capacity of iron plaque to immobilize $\mathrm{Pb}$ may also be related to other factors, such as the extent of plaque (Otte et al., 1989; Zhang et al., 1998), concentrations of metal and $\mathrm{pH}$ in the culture solution or rhizosphere, and capacity of oxidation and the age of roots (Ye et al., 1997; Batty et al., 2000; Liu et al., 2011; Mei et al., 2012).

Compared with that of the $\mathrm{Pb} 0$ treatment, the addition of $\mathrm{Pb}$ increased both $\mathrm{DCB}$-extracted $\mathrm{Fe}, \mathrm{Mn}$, and $\mathrm{Pb}$ concentrations in iron plaque and $\mathrm{HCl}$-extractable $\mathrm{Fe}, \mathrm{Mn}$, and $\mathrm{Pb}$ concentrations in the rhizosphere (Table 3), indicating that $\mathrm{Pb}$ addition stimulated the formation of iron plaque. Ksp of PbS $\left(3.4 \times 10^{-28}\right)$ is lower than Ksp of FeS $\left(3.7 \times 10^{-19}\right)$ and $\mathrm{MnS}\left(1.4 \times 10^{-18}\right)$. Thus, $\mathrm{S}^{2-}$ can mainly react with 
$\mathrm{Pb}$ to form $\mathrm{PbS}$ rather than reacting with $\mathrm{Fe}$ and $\mathrm{Mn}$ (Kashem and Singh, 2001; Beeston et al., 2010). Thus, Pb supply relatively induced the formation of iron plaque on the root surface of rice.

In summary, $\mathrm{S}$ supply affected $\mathrm{Pb}$ uptake and distribution in rice tissues in different ways: 1 ) moderate $S$ supply increased iron plaque on the root surface and in the rhizosphere; 2 ) excessive $S$ supply decreased iron plaque on the root surface; 3) S supply decreased $\mathrm{Pb}$ availability in soils; 4) S supply induced GSH formation in the leaves. Further studies are needed to investigate the dynamics of iron plaque formation on rice roots of different growth stages under various $\mathrm{S}$ levels.

\section{Acknowledgments}

The research was financially supported by the One Hundred Talents Program of the Chinese Academy of Sciences, 973 Program (2014CB238906), 863 Program (2013AA06A211-2), Beijing Municipal Science and Technology Project (Z131100003113008), Science and Technology Service Network Initiative (KFJ-EW-STS-014), and the National Natural Science Foundation of China (NSFC Nos. 41201312, 41271479, 41271478, and 41250110528).

\section{Appendix A. Supplementary Information}

Supplementary data associated with this article can be found in the online version at http://dx.doi.org/10.1016/j.ecoenv.2016.02.021.

\section{References}

Alexander, P.D., Alloway, B.J., Dourado, A.M., 2006. Genotypic variations in the accumulation of $\mathrm{Cd}, \mathrm{Cu}, \mathrm{Pb}$ and $\mathrm{Zn}$ exhibited by six common grown vegetables. Environ. Pollut. 144, 736-745.

Allen, S.E., 1989. Chemical Analysis of Ecological Materials, second ed. Blackwell Scientific Publications, Oxford.

Anjum, N.A., Umar, S., Singh, S., Nazar, R., Khan, N.A., 2008. Sulphur assimilation and cadmium tolerance in plants. In: Khan, N.A., Singh, S., Umar, S. (Eds.), Abiotic Stress and Sulphur Assimilation in Plants. Springer-Verlag, Berlin, pp. 271-302.

Batty, L.C., Baker, A.J.M., Wheeler, B.D., Curtis, C.D., 2000. The effect of pH and plaque on the uptake of $\mathrm{Cu}$ and $\mathrm{Mn}$ in Phragmites australis (Cav.) Trin ex, Steudel. Ann. Bot. 86, 647-653.

Beeston, M.P., Elteren, J.T., van, Šelih, V.S., Fairhurst, R., 2010. Characterization of artificially generated $\mathrm{PbS}$ aerosols and their use within a respiratory bioaccessibility test. Analyst 135, 351-357.

Butters, B., Chenery, E.M., 1959. A rapid method for the determination of total sulphur in soils and plants. Analyst 84, 239-245.

Canfield, D.E., Thamdrup, B., Kristensen, E., 2005. Aquatic geomicrobiology. In: Southward, A.J., Tyler, P.A., Young, C.M. (Eds.), Advances in Marine Biology 48. Academic Press Inc, US, pp. 314-373.

Cheng, H., Wang, M.Y., Wong, M.H., Ye, Z.H., 2014. Does radial oxygen loss and iron plaque formation on roots alter $\mathrm{Cd}$ and $\mathrm{Pb}$ uptake and distribution in rice plant tissues? Plant Soil 375, 137-148.

Fan, J.L., Hu, Z.Y., Ziadi, N., Xia, X., Yang, C., Wu, H., 2010. Excessive sulfur supply reduces cadmium accumulation in brown rice (Oryza sativa L.). Environ. Pollut. $158,409-415$.

Fan, J.L., Xia, X., Hu, Z.Y., Ziadi, N., Liu, C., 2013. Excessive sulfur supply reduces arsenic accumulation in brown rice. Plant Soil Environ. 59, 169-174.

Griffith, O.W., 1980. Determination of glutathione and glutathione disulfide using glutathione reductase and 2-vinylpyridine. Anal. Biochem. 106, 207-212.

Gupta, D.K., Huang, H.G., Corpas, F.J., 2013. Lead tolerance in plants: strategies for phytoremediation. Environ. Sci. Pollut. Res. 20, 2150-2161.

Hu, Z.Y., Xu, C.K., 2002. Soil sulfur and environmental quality. In: Chen, H.M. (Ed.), Behaviors of Chemical Substances in Soils and Environmental Quality. Science Press, Beijing, pp. 283-307 (in Chinese).

Hu, Z.Y. Zhu, Y.G. Li, M., Zhang, L.G., Cao, Z.H., Smith, F.A., 2007. Sulfur (S)-induced enhancement of iron plaque formation in the rhizosphere reduces arsenic accumulation in rice (Oryza sativa L.) seedlings. Environ. Pollut. 147, 387-393.

Islam, E., Liu, D., Li, T.Q., Yang, X.E., Jin, X.F., Mahmood, Q., Tian, S.K., Li, J.Y., 2008. Effect of $\mathrm{Pb}$ toxicity on leaf growth, physiology and ultrastructure in the two ecotypes of Elsholtzia argyi. J. Hazard. Mater. 154, 914-926.

Kashem, M.A., Singh, B.R., 2001. Metal availability in contaminated soils: II. Uptake of $\mathrm{Cd}, \mathrm{Ni}$ and $\mathrm{Zn}$ in rice plants grown under flooded culture with organic matter addition. Nutr. Cycl. Agroecosyst. 61, 257-266.
Khan, N.A., Singh, S., Umar, S., 2008. Sulfur Assimilation and Abiotic Stress in Plants. Springer-Verlag, Berlin, Heidelberg, pp. 111-148.

Kirk, P.L., 1950. Kjeldahl method for total nitrogen. Anal. Chem. 22, 354-358.

Lindsay, W.L., Norvell, W.A., 1978. Development of a DTPA soil test for zinc, iron, manganese, and copper. Soil Sci. Soc. Am. J. 42, 421-428.

Liu, J.G., Leng, X.M., Wang, M.X., Zhu, Z.Q., Dai, Q.H., 2011. Iron plaque formation on roots of different rice cultivars and the relation with lead uptake. Ecotoxicol. Environ. Saf. 74, 1304-1309.

Liu, J.G., Ma, X.M., Wang, M.X., Sun, X.W., 2013. Genotypic differences among rice cultivars in lead accumulation and translocation and the relation with grain $\mathrm{Pb}$ levels. Ecotoxicol. Environ. Saf. 90, 35-40.

Liu, W.J., Zhu, Y.G., Smith, F.A., Smith, S.E., 2004. Do phosphorus nutrition and iron plaque alter arsenate (As) uptake by rice seedlings in hydroponic culture? New Phytol. 162, 481-488.

Luo, C.L., Liu, C.P., Wang, Y., Liu, X., Li, F.B., Zhang, G., Li, X.D., 2011. Heavy metal contamination in soils and vegetables near an e-waste processing site, South China. J. Hazard. Mater. 186, 481-490.

McLaughlin, M.J., Parker, D.R., Clarke, J.M., 1999. Metals and micronutrients-food safe issues. Field Crop. Res. 60, 143-163.

Mei, X.Q., Ye, Z.H., Wong, M.H., 2009. The relationship of root porosity and radial oxygen loss on arsenic tolerance and uptake in rice grains and straw. Environ. 1 Pollut. 157 (8-9), 2550-2557.

Mei, X.Q., Wong, M.H., Yang, Y., Dong, H.Y., Qiu, R.L., Ye, Z.H., 2012. The effects of radial oxygen loss on arsenic tolerance and uptake in rice and on its rhizosphere. Environ. Pollut. 165, 109-117.

Murase, J., Kimura, M., 1997. Anaerobic reoxidation of $\mathrm{Mn}^{2+}, \mathrm{Fe}^{2+}, \mathrm{S}^{0}$ and $\mathrm{S}^{2-}$ in submerged paddy soils. Biol. Fertil. Soils 25, 302-306.

Olsen, S.R., Sommers, L.E., 1982. Phosphorus (Agron Monogr 9). In: Page, A.L. (Ed.), Methods of Soil Analysis, Part 2, second ed. ASA and AASA, Madison WI, pp. 403-430.

Otte, M.L., Rozema, J., Koster, L., Haarsma, M.S., Broekman, R.A., 1989. Iron plaque on roots of Aster tripolium L., interaction with zinc uptake. New Phytol. 111, 309-317.

Sun, Q., Ye, Z.H., Wang, X.R., Wong, M.H., 2005. Increase of glutathione in mine population of Sedum alfredii: a $\mathrm{Zn}$ hyperaccumulator and $\mathrm{Pb}$ accumulator. Phytochemistry 66, 2549-2556.

Taylor, G.J., Crowder, A.A., 1983. Use of DCB technique for extraction of hydrous iron oxides from roots of wetland plants. Am. J. Bot. 70, 1254-1257.

Thangavel, P., Long, S., Minocha, R., 2007. Changes in phytochelatins and their biosynthetic intermediates in red spruce (Picea rubens Sarg.) cell suspension culture under cadmium and zinc stress. Plant Cell Tissue Organ Cult. 88, 201-216.

Verma, B.C., Swaminathan, K., Sud, K.C., 1977. An improved turbidimetric procedure for the determination of sulphate in plants and soils. Talanta 24, 49-50.

Verma, S., Dubey, R.S., 2003. Lead toxicity induces lipid peroxidation and alters the activities of antioxidant enzymes in growing rice plants. Plant Sci. 164, 645-655.

Vesk, P.A., Nockold, C.E., Allaway, W.G., 1999. Metal localization in water hyacinth roots from an urban wetland. Plant Cell Environ. 22, 149-159.

Wang, T.J., Hu, Z.Y., Xie, M., Zhang, Y., Xu, C.K., Chao, Z.H., 2004. Atmospheric sulfur deposition onto different ecosystems over China. Environ. Geochem. Health 26 , 169-177.

Wasserman, G.A., Liu, X., Lolacono, N.J., Factor-Litvak, P., Kline, J.K., Popovac, D., Morina, N., Musabegovic, A., Vrenezi, N., Capuni-Paracka, S., Lekic, V., PreteniRedjepi, E., Hadzialjevic, S., Slavkovich, V., Graziano, J.H., 1997. Lead exposure and intelligence in 7-year-old children: the Yugoslavia prospective study. Environ. Health Perspect. 105, 956-962.

Warman, P.R., Sampson, H.G., 1992. Evaluation of soil sulfate extractants and methods of analysis for plant available sulfur. Commun. Soil Sci. Plant Anal. 23 793-803.

Yang, J.X., Ma, Z.L., Ye, Z.H., Guo, X.Y., Qiu, R.L., 2010. Heavy metal (Pb, Zn) uptake and chemical changes in rhizosphere soils of four wetland plants with different ROL. J. Environ. Sci. 22, 696-702.

Yang, J.X., Tam, N.F.Y., Ye, Z.H., 2014. Root porosity, radial oxygen loss and iron plaque on roots of wetland plants in relation to zinc tolerance and accumulation. Plant Soil 374, 815-828.

Yang, J.X., Guo, Q.J., Yang, J., Zhou, X.Y., Ren, H.Y., Zhang, H.Z., Xu, R.X., Wang, X.D. Peters, M., Zhu, G.X., Wei, R.F., Tian, L.Y., Han, H.K., 2016. Red mud (RM)-induced enhancement of iron plaque formation reduces arsenic and metal accumulation in two wetland plant species. Int. J. Phytoremediat. 18, 269-277.

Ye, Z.H., Baker, A.J.M., Wong, M.H., Willis, A.J., 1997. Zinc, lead and cadmium tolerance, uptake and accumulation by Typha latifolia. New Phytol. 136, 469-480.

Ye, Z.H., Baker, A.J.M., Wong, M.H., Willis, A.J., 1998. Zinc, lead and cadmium accumulation and tolerance in Typha latifolia as affected by iron plaque on the root surface. Aquat. Bot. 61, 55-67.

Ye, Z.H., Wong, M.H., Lan, C.Y., 2004. Use of a wetland system for treating $\mathrm{Pb} / \mathrm{Zn}$ mine effluent:a case study in southern China from 1984 to 2002. In: Wong, M. H. (Ed.), Wetland Ecosystems in Asia: Function and Management. Elsevier, Amsterdam, pp. 413-434.

Zhang, W., Lin, K.F., Zhou, J., Zhang, W., Liu, L.L., Han, X.L., 2013. Spatial distribution and toxicity of cadmium in the joint presence of sulfur in rice seedling. Environ. Toxicol. Pharmacol. 36, 1235-1241.

Zhang, X.K., Zhang, F.S., Mao, D.R., 1998. Effect of Fe plaque outside roots on nutrient uptake by rice (Oryza sativa L.): zinc uptake. Plant Soil 202, 33-39.

Zhuang, P., McBride, M.B., Xia, H.P., Li, N.Y., Li, Z.A., 2009. Health risk from heavy metals via consumption of food crops in the vicinity of Dabaoshan mine, South China. Sci. Total Environ. 407, 1551-1561. 